\title{
Devise of a W Serpentine Shape Tube Heat Exchanger in a Hard Chromium Electroplating Process
}

Surasit Tanthadiloke ${ }^{\mathrm{a}}$, Paisan Kittisupakorn ${ }^{\mathrm{a}, *}$, Pannee Boriboonsri ${ }^{\mathrm{a}}$, Iqbal M. Mujtaba ${ }^{\mathrm{b}}$

a Department of Chemical Engineering, Faculty of Engineering, Chulalongkorn University, Bangkok 10330, Thailand

b School of Engineering, University of Bradford, West Yorkshire BD7 1DP, UK

\section{Corresponding Author:}

Professor Paisan Kittisupakorn, Ph.D.

Department of Chemical Engineering

Faculty of Engineering, Chulalongkorn University

254 Phayathai Road, Pathumwan, Bangkok, 10330, Thailand

Phone: +66-2218-6878

Fax: +66-2218-6877

E-mail address: paisanpse@hotmail.com, paisan.k@chula.ac.th 
Energy, Resources and Environmental Technology

2 Devise of a W Serpentine Shape Tube Heat Exchanger

3 in a Hard Chromium Electroplating Process

4 Surasit Tanthadiloke ${ }^{1}$, Paisan Kittisupakorn ${ }^{1, *}$,

5 Pannee Boriboonsri ${ }^{1}$, Iqbal M. Mujtaba ${ }^{2}$

$6 \quad{ }^{1}$ Department of Chemical Engineering, Faculty of Engineering,

7 Chulalongkorn University, Bangkok 10330, Thailand

$8 \quad{ }^{2}$ School of Engineering, University of Bradford, West Yorkshire BD7 1DP, UK

\section{Abstract}

In a hard chromium electroplating process, a heat exchanger is employed to remove the heat produced from the high current intensity in an electroplating bath. Normally, a conventional U shape heat exchanger is installed in the bath but it provides low heat removal. Thus, this study designs a novel $\mathrm{W}$ serpentine shape heat exchanger with identical heat transfer area to the conventional one for increasing heat removal performance. The performance of the heat exchange is tested with various flow velocities in a cross-section in range of 1.6 to $2.4 \mathrm{~m} \cdot \mathrm{s}^{-1}$. Mathematical models of this process have been formulated in order to simulate and evaluate the heat exchanger performance. The results show that the developed models give a good prediction of the plating solution and cooling water temperature and the novel heat exchanger provides better results at any flow velocity. In addition, the $\mathrm{W}$ serpentine shape heat exchanger has been implemented in a real hard chromium electroplating plant. Actual data collected have shown that the new design gives higher heat removal performance compared with the $U$ shape heat exchanger with identical heat transfer area; it removes more heat out of the process than the conventional one of about $23 \%$. 
Keyword: W serpentine shape; Hard chromium electroplating; Mathematical modeling; Simulation; Heat exchanger.

Corresponding author, Tel: +66 22186878 Fax: +66 22186877

E-mail: paisanpse@hotmail.com, paisan.k@chula.ac.th (P. Kittisupakorn)

\section{Introduction}

A hard chromium electroplating process is one kind of chromium electroplating. This process is usually applied for protecting the surface of base materials against a harmful environment, extending the maintenance time and increasing the material properties i.e. corrosive resistance, wear resistance and shear stress $[1,2]$. In the hard chromium electroplating process, the workpieces such as pistons, rollers, gaskets, vehicle molds and electrical parts, etc. are coated with the chromium metal from 2.5 to $500 \mu \mathrm{m}$ in thickness [3]. Generally, the performance of this plating and the probability of defect occurrence on coated products are depended on the operating conditions during the plating period such as the concentration of plating solution, current density, power voltage and temperature $[4,5]$. To provide the best quality of the coated products, the optimal range for the hard chromium electroplating is in range of $(50 \pm 3){ }^{\circ} \mathrm{C}[5,6]$. All unit operations in the hard chromium electroplating process are shown in Fig. 1. This process comprises of an electroplating bath with an immersed tube heat exchanger that is also connected to a cooling tower. The cooling water is a media to deliver the heat from the bath and to cool the plating solution through the heat exchanger. When the cooling water temperature is high after flowing through the electroplating bath, the cooling tower takes away the heat and supplies the low temperature cooling water to the bath again. 


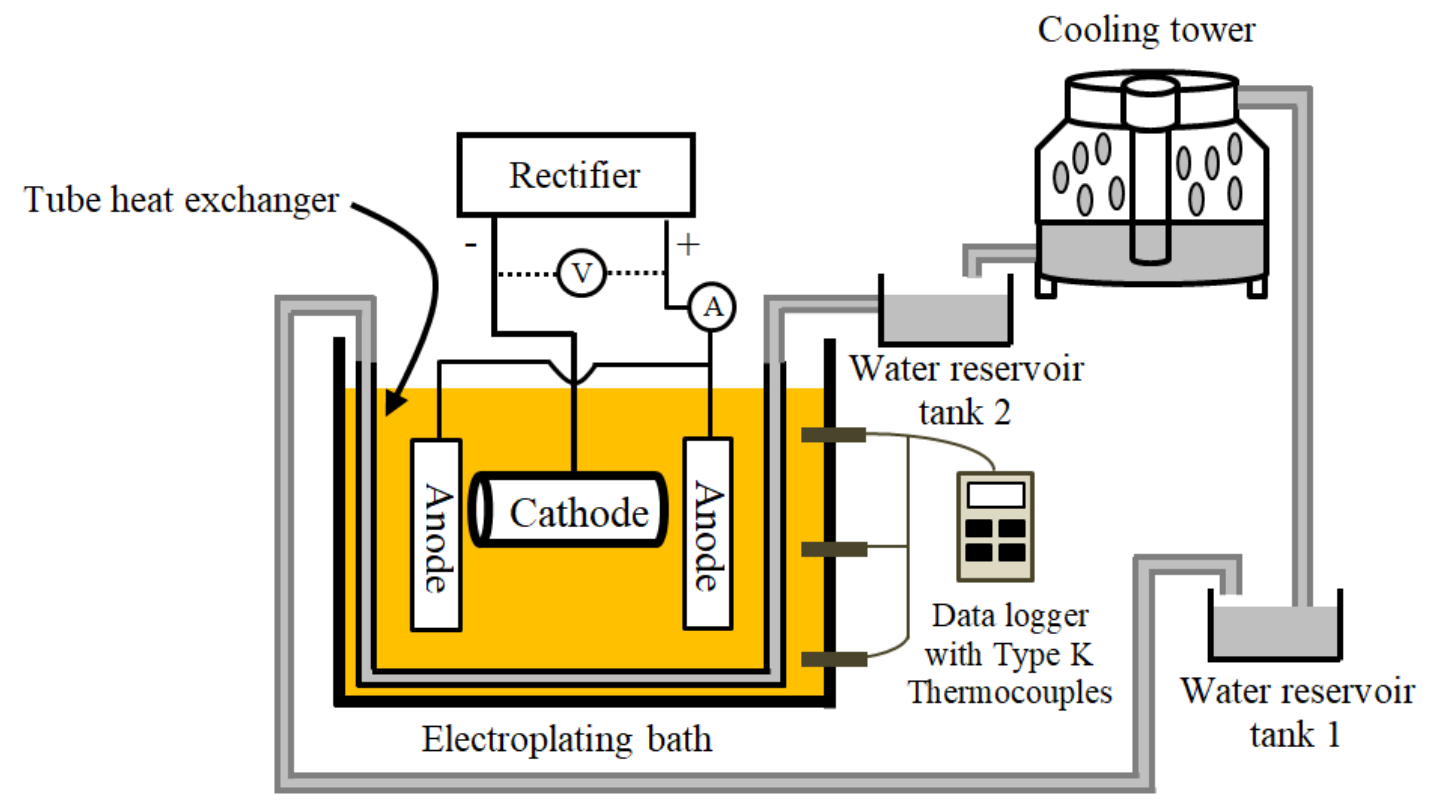

Fig. 1 Hard chromium electroplating process with the cooling system.

However, the main factor affected on the product quality is the temperature of the plating solution during the operation. Due to the fact that the plating solution temperature is continually raised by the heat produced from the high current load during the plating time, then the accumulated heat of plating solution can cause the defects on the surface of products. When this problem takes place, the defected products are recoating again [7]. Since this high temperature problem is normally found in the hard chromium electroplating plant, an effective heat exchanger is needed to keep the plating solution temperature in the optimal range around 47 to $53{ }^{\circ} \mathrm{C}$ along the plating period [8].

In general, a conventional $U$ shape tube heat exchanger is installed at the wall of the electroplating bath. This pipe is made of the titanium to protect against the corrosion from the chromic acid. Normally, the U shape tube heat exchanger in the bath is placed in parallel with the direction of heat flow which directly affects to heat transfer coefficient [9]. Then, it leads to the thermal resistance film that reduces the heat transfer between two fluids, at the outer surface 
61 of the tube [10]. In order to improve the heat transfer coefficient of the tube heat exchanger, piping patterns or shape of heat exchangers reported by recent literatures such as a spiral corrugated tube $[11,12]$, a curved tube $[13,14]$, an inserted triangle coil tube $[15,16]$ and a vibrating tube $[17,18]$ have been studied. To evaluate the performance of the heat exchanger, mathematical models of the process and heat exchangers are also developed.

The objective of this work is to devise a novel heat exchanger for the hard chromium electroplating process to improve the heat transfer coefficient. In addition, the mathematical models of the hard chromium electroplating process and the heat exchangers have been developed and validated with the actual data. The developed models have been used to study the temperature profile and the heat removal performance of the conventional $U$ shape and the novel design heat exchangers. Finally, the novel design heat exchanger has been implemented in the bath and its performance has been evaluated.

\section{Methods}

\subsection{Process overview}

A hard chromium electroplating process in this study consists of an electroplating bath (1.7 $\mathrm{m}$ diameter and $4.5 \mathrm{~m}$ height), a tube heat exchanger, two reservoir tanks of cooling water and a cooling tower as shown in Fig.1. In this process, the height of plating solution is $4 \mathrm{~m}$ from the bottom of the bath and the objects to be plated are connected with the rectifier and are submerged into the plating solution. The conventional $U$ shape tube heat exchanger $(2.54 \mathrm{~cm}$ diameter and $30 \mathrm{~m}$ in total length) with cooling water as the medium is installed inside the bath for removing any heat generated from the electrical current. Then, the high temperature cooling water from all electroplating baths collected at the first water reservoir tank are fed into the cooling tower in order to cool down its temperature to about $34{ }^{\circ} \mathrm{C}$. After that, the cooling water 
is recirculated to the electroplating bath again. Some amounts of cooling water are loss from the drag out, wind and evaporation at the reservoir tanks and the cooling tower. In order to collect the data from the real plant, a data logger connected with Type $\mathrm{K}$ Thermocouples is used for this purpose. Three thermocouples are placed at $1 \mathrm{~m}, 2 \mathrm{~m}$ and $3.5 \mathrm{~m}$ from the plating solution surface in order to observe the temperatures in the bath during 8 hours of the operation and the plating bath temperatures can be collected and used to validate the mathematical models of the bath.

\subsection{Devise of the $W$ serpentine shape tube heat exchanger}

The novel heat exchanger of this work is devised with a pattern of W serpentine shape [Fig. 2(b)]. This new design attempts to prevent the thermal resistance film formulation by introducing inclined and curve shapes that give the unparalleled flow direction of the cooling water and the plating solution. Thus, the $\mathrm{W}$ shape heat exchanger has less the thermal resistance film formulation at the outer tube surface resulting in more heat transfer rate than the original one. In addition, the curve design of the $\mathrm{W}$ shape induces the secondary flow of the cooling water inside the tube $[19,20]$ that enhances the heat transfer rate between the plating solution and the cooling water $[21,22]$. Titanium is chosen as the piping material for this novel heat exchanger. In this study, the $\mathrm{W}$ serpentine shape heat exchangers with 1.27 and $2.54 \mathrm{~cm}$ diameter, which have the identical heat transfer area as to the $\mathrm{U}$ shape heat exchanger, are designed to compare the performance. Furthermore, the heat exchangers are tested with various flow velocities in a crosssection at 1.6, 2.0 and $2.4 \mathrm{~m} \cdot \mathrm{s}^{-1}$ for evaluating its performance. In order to obtain the same flow velocity in each heat exchanger, the volumetric water flow rates at $1.55 \times 10^{-4}, 1.94 \times 10^{-4}$ and $2.32 \times 10^{-4} \mathrm{~m}^{3} \cdot \mathrm{s}^{-1}$ are used for the $1.27 \mathrm{~cm}$ diameter heat exchanger and the volumetric water flow rates at $7.12 \times 10^{-4}, 8.9 \times 10^{-4}$ and $10.68 \times 10^{-4} \mathrm{~m}^{3} \cdot \mathrm{s}^{-1}$ are used for the $2.54 \mathrm{~cm}$ diameter heat exchanger. 


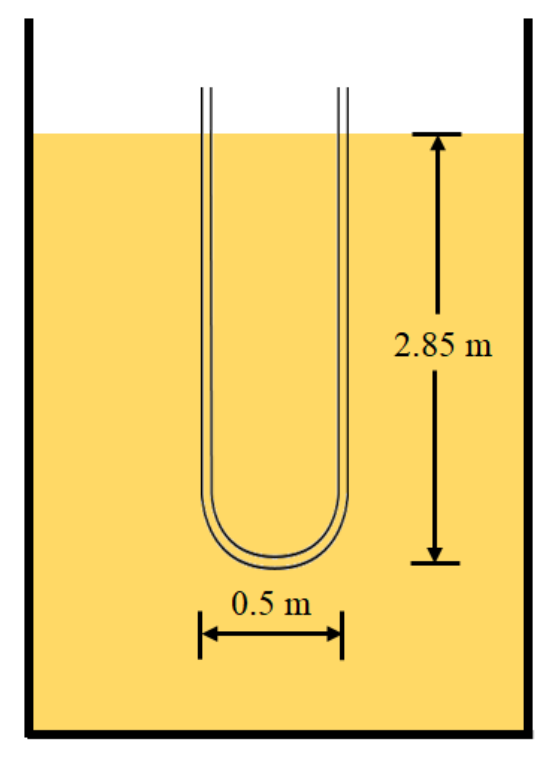

(a)

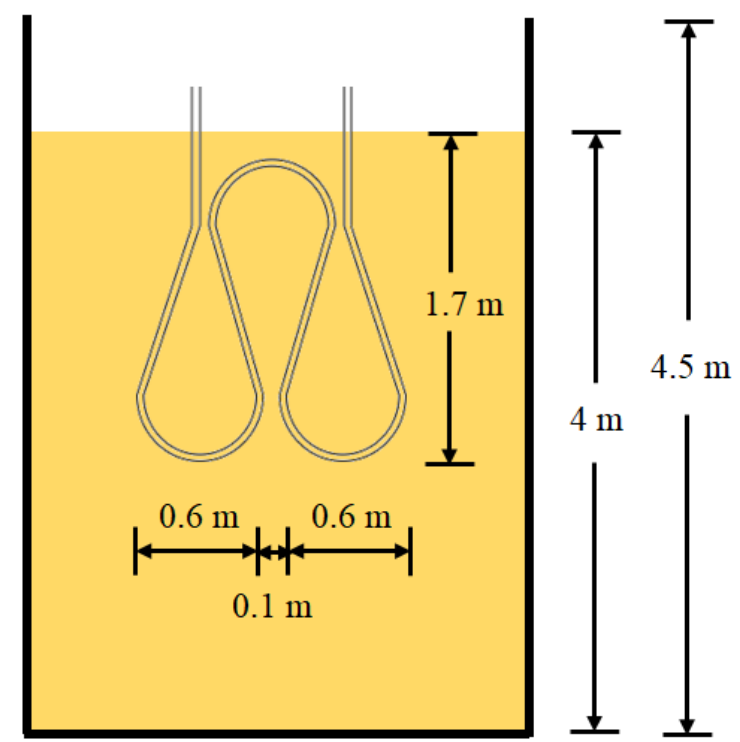

(b)

Fig. 2 Illustration of the heat exchangers inside the hard chromium electroplating bath: (a) U shape heat exchanger and (b) W serpentine shape heat exchanger.

\subsection{Assumptions}

To derive the equations for the hard chromium electroplating process, the following assumptions are made as follows,

- The variation of the plating solution concentration is negligible.

- The physical and chemical properties of the plating solution such as density or heat capacity are constant along the plating period.

- The electroplating bath is well-mixed.

- The heat generated from electroplating current load is remarkably significant compared to heat released from chemical reactions.

- Heat loss of the cooling water in the heat exchanger outside the bath to the surrounding is negligible. 
124 (Fig. 3) are based on the principle of mass and energy conservation [23, 24].

125

126

127

128

129

130

131

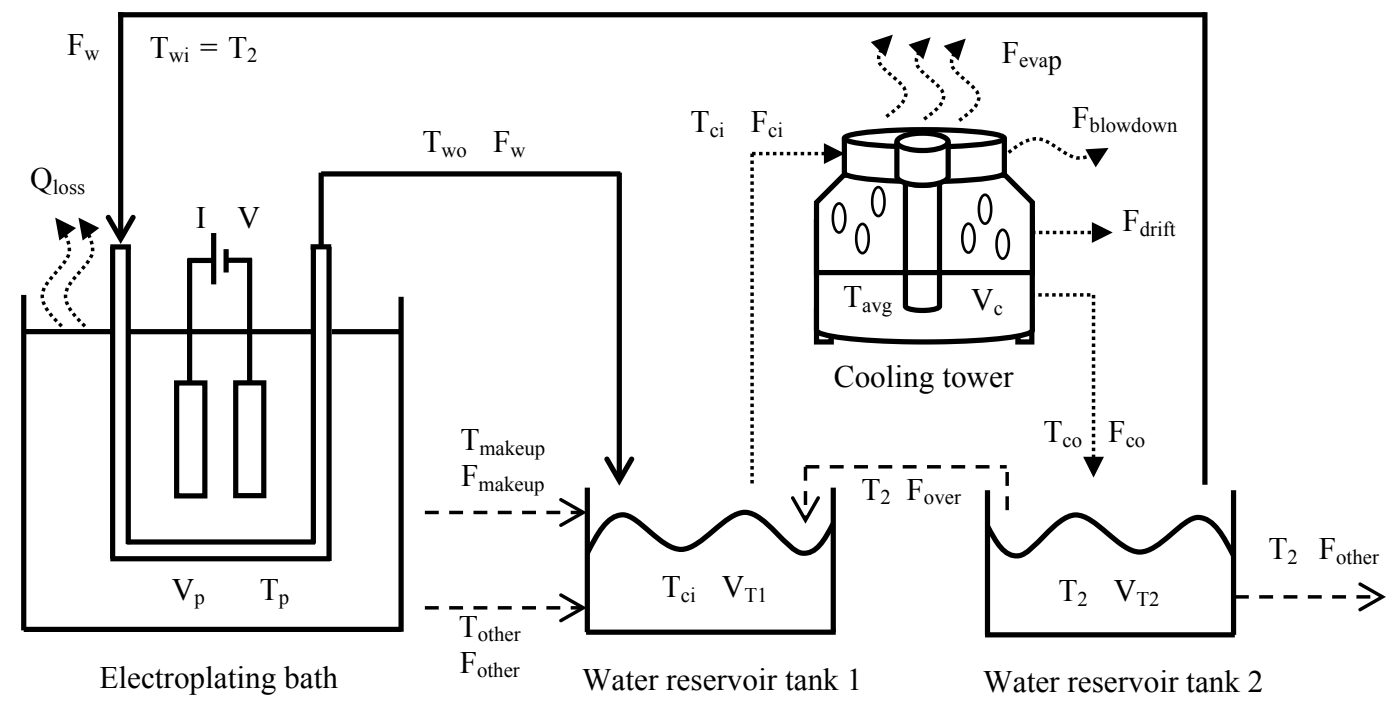

Fig. 3 Schematic diagram of the hard chromium electroplating process with mass and energy balance.

\subsubsection{The electroplating bath}

Mass conservation equation

Energy conservation equation

$$
\frac{\mathrm{d}\left(\rho_{\mathrm{p}} V_{p}\right)}{\mathrm{d} t}
$$

$$
\frac{\mathrm{d} T_{\mathrm{p}}}{\mathrm{d} t}=\frac{I V-Q_{\mathrm{loss}}-F_{\mathrm{t}} U_{0} A_{\mathrm{ht}} \Delta T_{\mathrm{lm}}}{\rho_{\mathrm{p}} C_{p \mathrm{p}} V_{\mathrm{p}}}
$$

The equation of energy conservation in Eq. (2) contains the heat production owing to the power current load, the heat loss at the upper surface of the plating solution to the surrounding and the term related to heat transfer between the electroplating bath and the heat exchanger. The 
$136 Q_{\text {loss }}$ term related on the power current load and plating solution temperature is calculated from

137 Eq. (3).

$$
Q_{\text {loss }}=f(I V)+\left(0.0196 T_{\mathrm{p}}^{2.8806}+2.1527 T_{\mathrm{p}}-32.655\right) A_{\text {sur }}
$$
relation of the actual data between the plating solution temperature and the current load.

\subsubsection{The tube heat exchanger}

142

143

144

145

146

147

148

149

150

151

152
The energy conservation equation of the tube heat exchanger that immersed in the electroplating bath is applied using a lumped model [25], while a constant volumetric water flow rate is considered on the mass balance.

Mass conservation equation

$$
\frac{\mathrm{d}\left(\rho_{\mathrm{w}} V_{\text {tube }}\right)}{\mathrm{d} t}=0
$$

Energy conservation equation

$$
\frac{\mathrm{d} T_{\mathrm{wo}}}{\mathrm{d} t}=\frac{F_{\mathrm{w}}\left(T_{\mathrm{wi}}-T_{\mathrm{wo}}\right)}{L_{\text {tube }} A_{\mathrm{o}}}+\frac{F_{\mathrm{t}} U_{\mathrm{o}} A_{\mathrm{ht}} \Delta T_{\mathrm{lm}}}{\rho_{\mathrm{w}} C_{\mathrm{pw}} L_{\text {tube }} A_{\mathrm{o}}}
$$

Where $U_{0}$ refers to the overall heat transfer coefficient, $\Delta T_{\operatorname{lm}}$ expresses to the logarithmic mean temperature and can be computed by Eq. (6). The right term of energy balance in Eq. (5) is constituted of the different of heat flow between outlet and inlet tube heat exchanger and the heat exchanged with the electroplating bath and heat exchanger.

$$
\Delta T_{\mathrm{lm}}=\frac{T_{\mathrm{wo}}-T_{\mathrm{wi}}}{\ln \left[\frac{T_{\mathrm{p}}-T_{\mathrm{wi}}}{T_{\mathrm{p}}-T_{\mathrm{wo}}}\right]}
$$




\subsubsection{The cooling system}

The cooling system composes two water reservoir tanks and a cooling tower. The water flowing from the tube heat exchanger to a tank 1 is delivered to the cooling tower in order to reduce its temperature. The cooling water flows from the cooling tower to a tank 2 before entering to the electroplating bath. Eq. (7) to Eq. (9) provide the mass conservation equations for both tanks and the cooling tower, respectively.

Mass conservation equations

$$
F_{\mathrm{co}}=F_{\mathrm{ci}}-F_{\text {makeup }}(7)
$$

$$
F_{\text {over }}=F_{\text {co }}-F_{\text {w }}-F_{\text {other }}
$$

$$
F_{\text {makeup }}=F_{\text {blowdown }}+F_{\text {evap }}+F_{\text {drift }}
$$

The water makeup of the cooling tower in Eq. (9) consists of the summation of blowdown, evaporation loss and drift loss [26]. Blowdown discards a portion of the concentrated circulating water due to the evaporation process in order to lower the system solid concentration. Drift loss is entrained water that carried out from the cooling tower by the wind.

$$
\begin{aligned}
& \frac{\mathrm{d} T_{\mathrm{ci}}}{\mathrm{d} t}=\frac{F_{\mathrm{w}} T_{\mathrm{wo}}+F_{\text {makeup }} T_{\text {makeup }}-F_{\mathrm{ci}} T_{\mathrm{ci}}}{V_{\mathrm{T} 1}}+\frac{F_{\text {other }} T_{\text {other }}+F_{\text {over }} T_{2}}{V_{\mathrm{T} 1}} \\
& \frac{\mathrm{d} T_{2}}{\mathrm{~d} t}=\frac{F_{\mathrm{co}} T_{\mathrm{co}}-F_{\mathrm{w}} T_{2}-F_{\text {over }} T_{2}-F_{\mathrm{other}} T_{2}}{V_{\mathrm{T} 2}} \\
& \frac{\mathrm{d} T_{\mathrm{co}}}{\mathrm{d} t}=\frac{F_{\mathrm{ci}} T_{\mathrm{ci}}-F_{\mathrm{co}} T_{\mathrm{co}}-F_{\text {makeup }} T_{\mathrm{avg}}-\frac{h_{\mathrm{A}} A_{\mathrm{s}}\left(T_{\text {avg }}-T_{\text {air }}\right)}{\rho_{\mathrm{w}} C_{\mathrm{pw}}}-\frac{F_{\text {evap }} \lambda_{\text {evap }}}{C_{\mathrm{pw}}}}{V_{\mathrm{c}}}
\end{aligned}
$$

The three terms in the energy conservation equation of the cooling tower as shown in Eq. (12) demonstrate the difference of heat flow between outlet and inlet of the cooling tower with 
174 the last two terms showing the heat transferred by convection and evaporation, respectively.

175 Term of $h_{\mathrm{A}} A_{\mathrm{S}}$ can be obtained by the least squares method with the water temperature profile at

176 the cooling tower. The $T_{\text {avg }}$ in the above equation is calculated by

177

$$
T_{\mathrm{avg}}=\frac{T_{\mathrm{ci}}+T_{\mathrm{co}}}{2}
$$

179 conductive resistance, while the fouling is negligible. In case of both U shape and W shape tube

180 heat exchangers, the overall heat transfer coefficients are calculated by optimization based on

181 actual data. The optimization problem can be formulated as follows: 


\section{Table 1}

188 Physical properties [27, 28].

\begin{tabular}{cc}
\hline Physical property & Value \\
\hline Density of water $/ \mathrm{kg} \cdot \mathrm{m}^{-3}$ & 992.25 \\
Density of plating solution $/ \mathrm{kg} \cdot \mathrm{m}^{-3}$ & $1,174.4$ \\
Heat capacity of water $/ \mathrm{kJ} \cdot \mathrm{kg}^{-1 .{ }^{\circ} \mathrm{C}^{-1}}$ & 4.181 \\
Heat capacity of plating solution $/ \mathrm{kJ} \cdot \mathrm{kg}^{-1 .{ }^{\circ}} \mathrm{C}^{-1}$ & 4.917 \\
Latent heat of vaporization of water $/ \mathrm{kJ} \cdot \mathrm{kg}^{-1}$ & 2,260 \\
Thermal conductivity of titanium $/ \mathrm{kW} \cdot \mathrm{m}^{-1 .} \mathrm{C}^{-1}$ & 0.0206 \\
\hline
\end{tabular}

\section{Table 2}

191 Simulation system geometric characteristics.

\begin{tabular}{cc}
\hline System characteristic & Value \\
\hline Inner diameter of a $1.27 \mathrm{~cm}$ diameter tube heat exchanger $/ \mathrm{m}$ & 0.0111 \\
Outer diameter of a $1.27 \mathrm{~cm}$ diameter tube heat exchanger $/ \mathrm{m}$ & 0.0127 \\
Inner diameter of a $2.54 \mathrm{~cm}$ diameter tube heat exchanger $/ \mathrm{m}$ & 0.0238 \\
Outer diameter of a $2.54 \mathrm{~cm}$ diameter tube heat exchanger $/ \mathrm{m}$ & 0.0254 \\
Volume of an electroplating bath $/ \mathrm{m}^{3}$ & 9.3062 \\
Volume of a water tank $1 / \mathrm{m}^{3}$ & 2.1155 \\
Volume of a water tank $2 / \mathrm{m}^{3}$ & 2.5663 \\
Volume of a cooling tower $/ \mathrm{m}^{3}$ & 0.3771 \\
\hline
\end{tabular}

\section{Table 3}

\begin{tabular}{cc}
\hline Operating condition & Value \\
\hline Outlet water temperature to other electroplating baths $/{ }^{\circ} \mathrm{C}$ & 44.1 \\
\hline
\end{tabular}




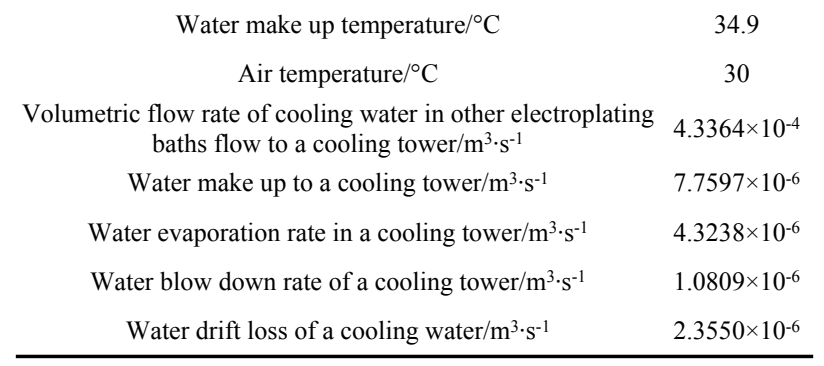

194

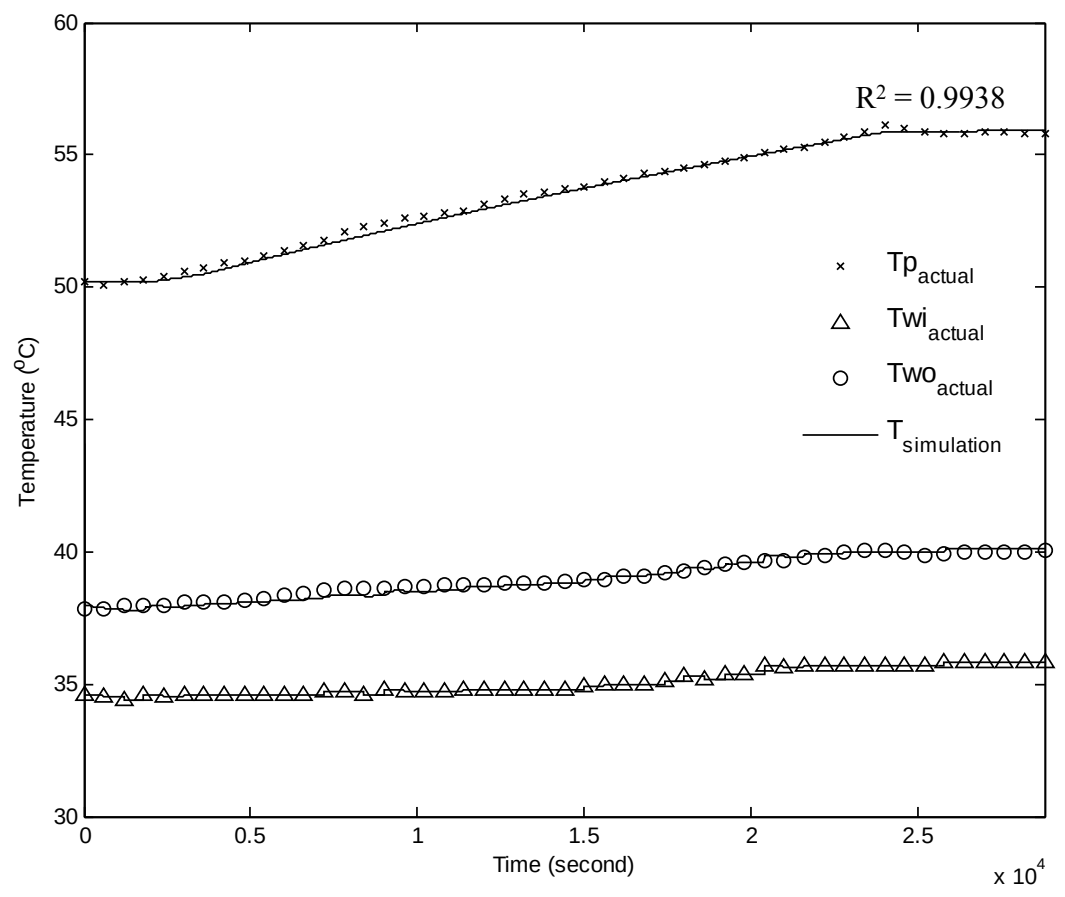

195
Fig. 4 Comparison results between simulation and actual data of plating solution temperature and water temperature at inlet and outlet of the electroplating bath.

Since the workpieces require a high thickness of hard chromium coating, the current load of electroplating is supplied at a high rate. The high current load can lead to the increase in the plating solution temperature if the heat removed out of the solution by the heat exchanger is lower than that of the heat generated from the current load. Fig. 4 shows a good agreement between simulation results and the actual data with the coefficient of determination $\left(R^{2}\right)$ of more than $90 \%$ so the mathematical models of this process can be used to predict the temperature 204 profile of the process. 


\section{Results \& Discussion}

\subsection{Simulation results}

Fig. 5 and Fig .6 demonstrate the temperature profile of the plating solution, water inlet and outlet at the electroplating bath for the W serpentine shape with diameters of 1.27 and $2.54 \mathrm{~cm}$ comparing to the conventional $U$ shape tube heat exchanger. To test the heat exchangers, the

210 cooling water flow velocities of $1.6,2.0$ and $2.4 \mathrm{~m} \cdot \mathrm{s}^{-1}$ are introduced in this study. These results

211 show that the plating solution temperature profiles of both sizes of the $\mathrm{W}$ serpentine shape are

212 lower than that of the U shape heat exchanger. Since, the new design has the combination of the

213 inclined and curved shapes which makes an unparalleled flow direction between the cooling

214 water and the plating solution inside the bath. This prevents the formulation of thermal resistance

215 film at the outer tube surface that resulting in enhances the heat transfer rate [10].

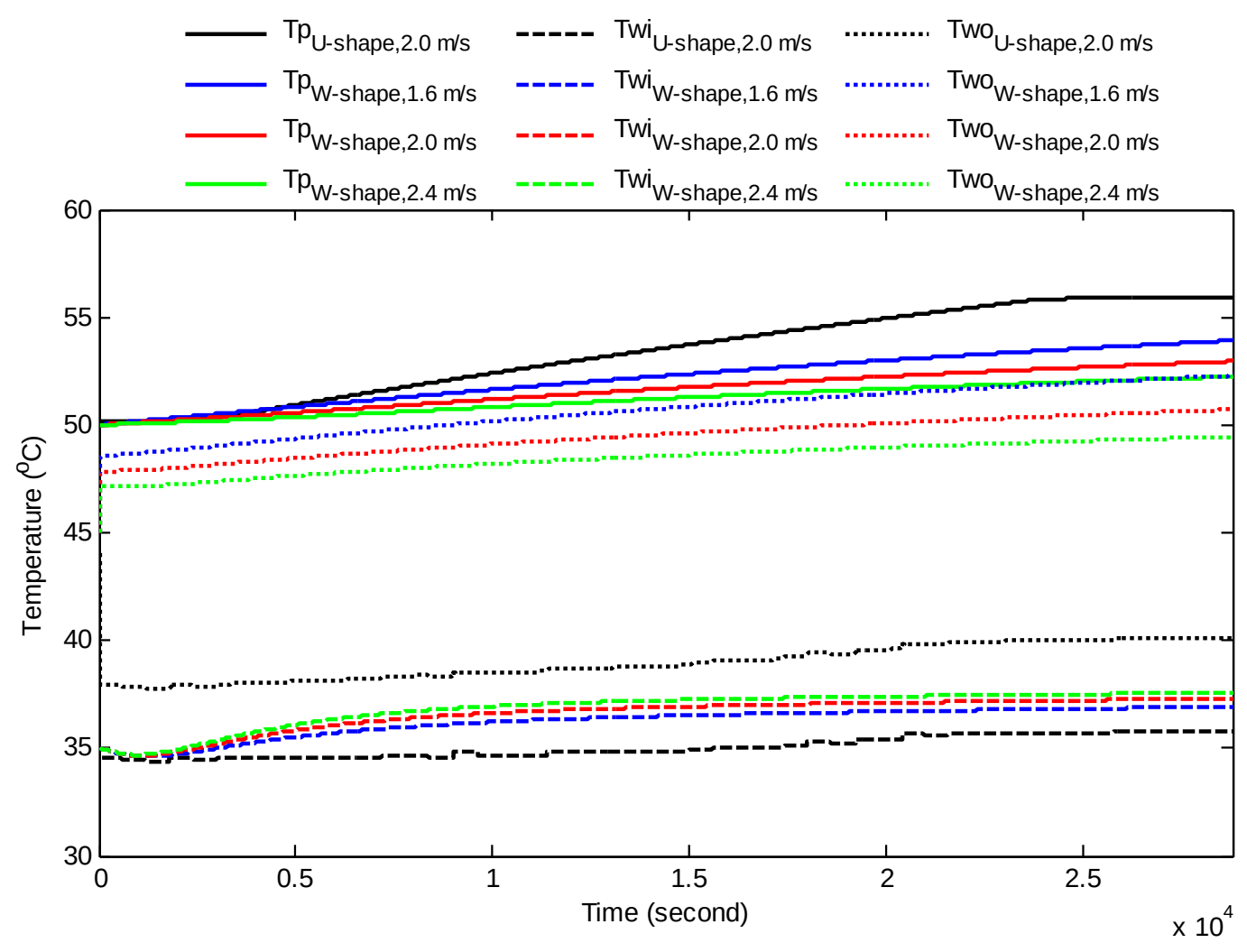


Fig. 5 The temperature profile of plating solution, water inlet and outlet at the electroplating bath for $1.27 \mathrm{~cm}$ diameter of $\mathrm{W}$ serpentine shape tube heat exchanger at various water velocities.

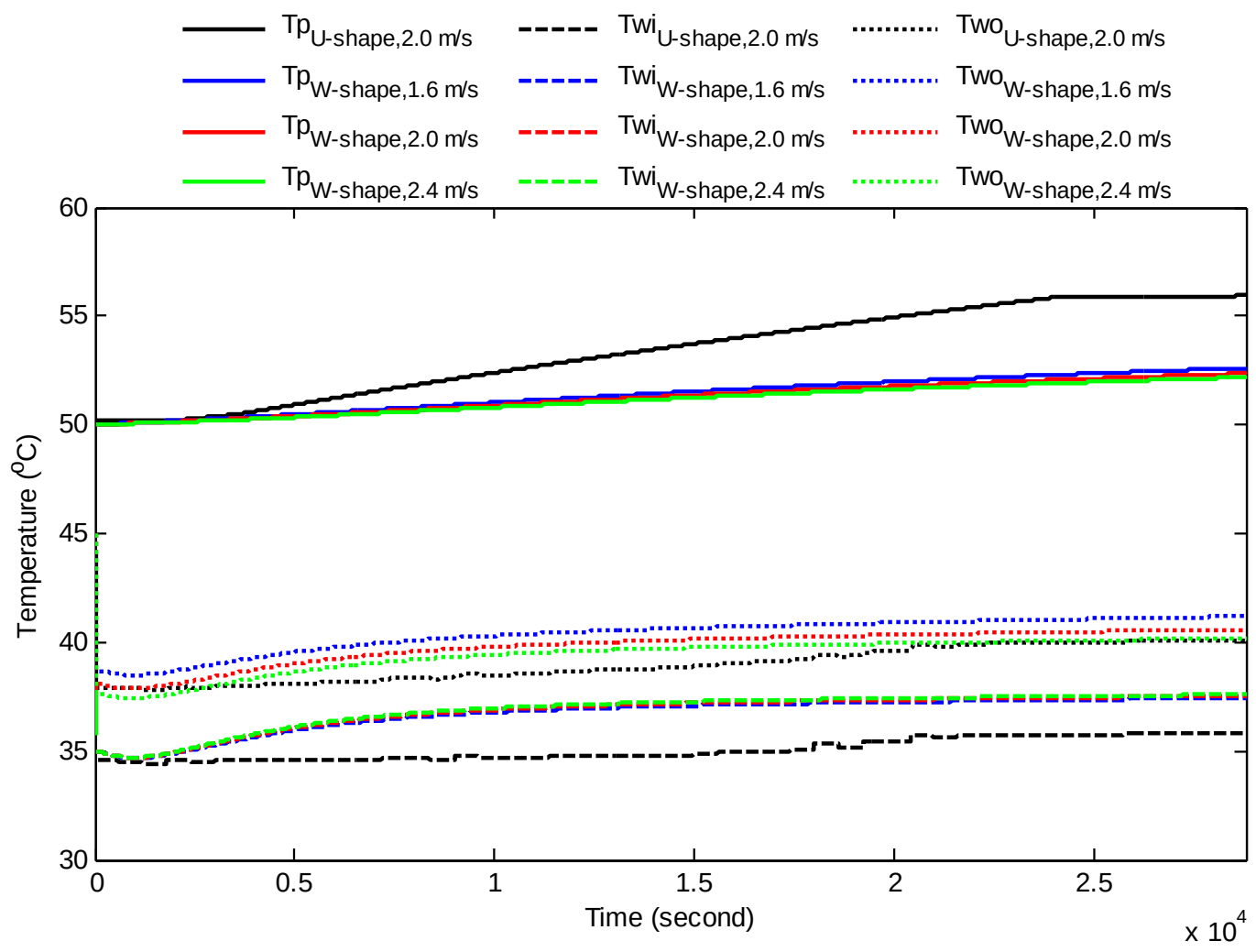

Fig. 6. The temperature profile of plating solution, water inlet and outlet at the electroplating bath for $2.54 \mathrm{~cm}$ diameter of $\mathrm{W}$ serpentine shape tube heat exchanger at various water velocities. 
Furthermore, the curve shape of this devised heat exchanger increases the heat transfer rate between the plating solution and the cooling water from the secondary flow of the cooling water inside the tube [20, 21, 22]. In Fig. 5, when current load is applied to the electroplating bath during the 8 hours of operation, the $1.27 \mathrm{~cm}$ diameter of the $\mathrm{W}$ shape heat exchanger with 2.4 $\mathrm{m} \cdot \mathrm{s}^{-1}$ of flow velocity can adequately remove the heat that generated from the bath and the temperature of the plating solution can be maintained in the optimal range of $(50 \pm 3)^{\circ} \mathrm{C}$. However, in the case of $1.6 \mathrm{~m} \cdot \mathrm{s}^{-1}$ of flow velocity, the temperature difference between plating solution and water at the outlet is small. As a consequence, the heat removal is insufficient to maintain the plating solution temperature at the optimal range; the temperature of the bath is more than $53{ }^{\circ} \mathrm{C}$. Nevertheless, the result of the $\mathrm{W}$ serpentine shape with $2.54 \mathrm{~cm}$ diameter in Fig. 6 shows that the cooling water at all velocities can remove the generated heat from the process and the plating solution temperature can be kept at the optimal range along the electroplating period; the maximum temperature of the plating solution is $52.6,52.3$ and $52.2{ }^{\circ} \mathrm{C}$ at 1.6, 2.0 and $2.4 \mathrm{~m} \cdot \mathrm{s}^{-1}$ of flow velocities, respectively. With these results, thus the $\mathrm{W}$ serpentine shape with $2.54 \mathrm{~cm}$ diameter is selected for implementation at the real plant.

\subsection{Implementation results of the $W$ serpentine shape tube heat exchanger}

According to the simulation study, the $\mathrm{W}$ serpentine shape tube heat exchanger requires the $2.54 \mathrm{~cm}$ diameter and $30 \mathrm{~m}$ in total length. However, in practical and due to the limitations of the free space for installation inside the real electroplating bath, this heat exchanger is divided into four pieces. Each piece has a diameter of $2.54 \mathrm{~cm}$ and a length of $7.5 \mathrm{~m}$ (Fig. 7), which is conveniently implemented in the real bath. Each heat exchanger is immersed in half of plating solution depth because a large amount of heat from the hard chromium electroplating process 
247 releases at this position. The end of both sides is connected with a polyvinylchloride (PVC) tube 248 to supply and recirculate the cooling water.

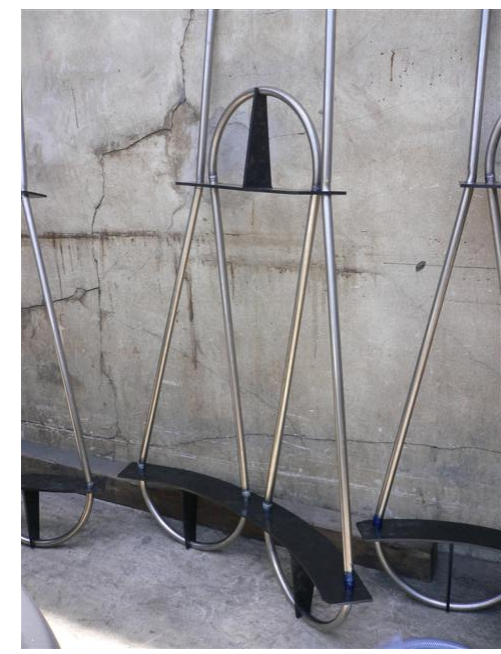

(a) The W serpentine shape tube heat exchanger.

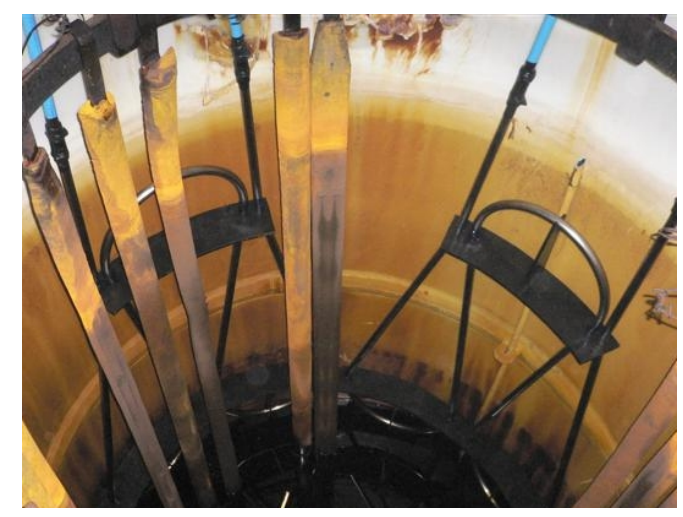

(b) The installation of the W serpentine shape tube heat exchanger in the electroplating bath.

Fig. 7 The implementation of W serpentine shape tube heat exchanger.

Fig.8 demonstrates the actual data after the implementation of the $\mathrm{W}$ serpentine shape tube heat exchanger and the $\mathrm{U}$ shape tube heat exchanger. The result indicates that the $\mathrm{W}$ serpentine shape tube heat exchanger can keep the plating solution temperature during the plating period lower than the original one. The plating solution temperature can be kept in the range of 50 $53^{\circ} \mathrm{C}$ during the plating period and the water outlet temperature is about $39-42^{\circ} \mathrm{C}$. With the 
259 collected data, the novel W serpentine shape tube heat exchanger removes more heat out of the 260 process than the conventional heat exchanger around $23 \%$.

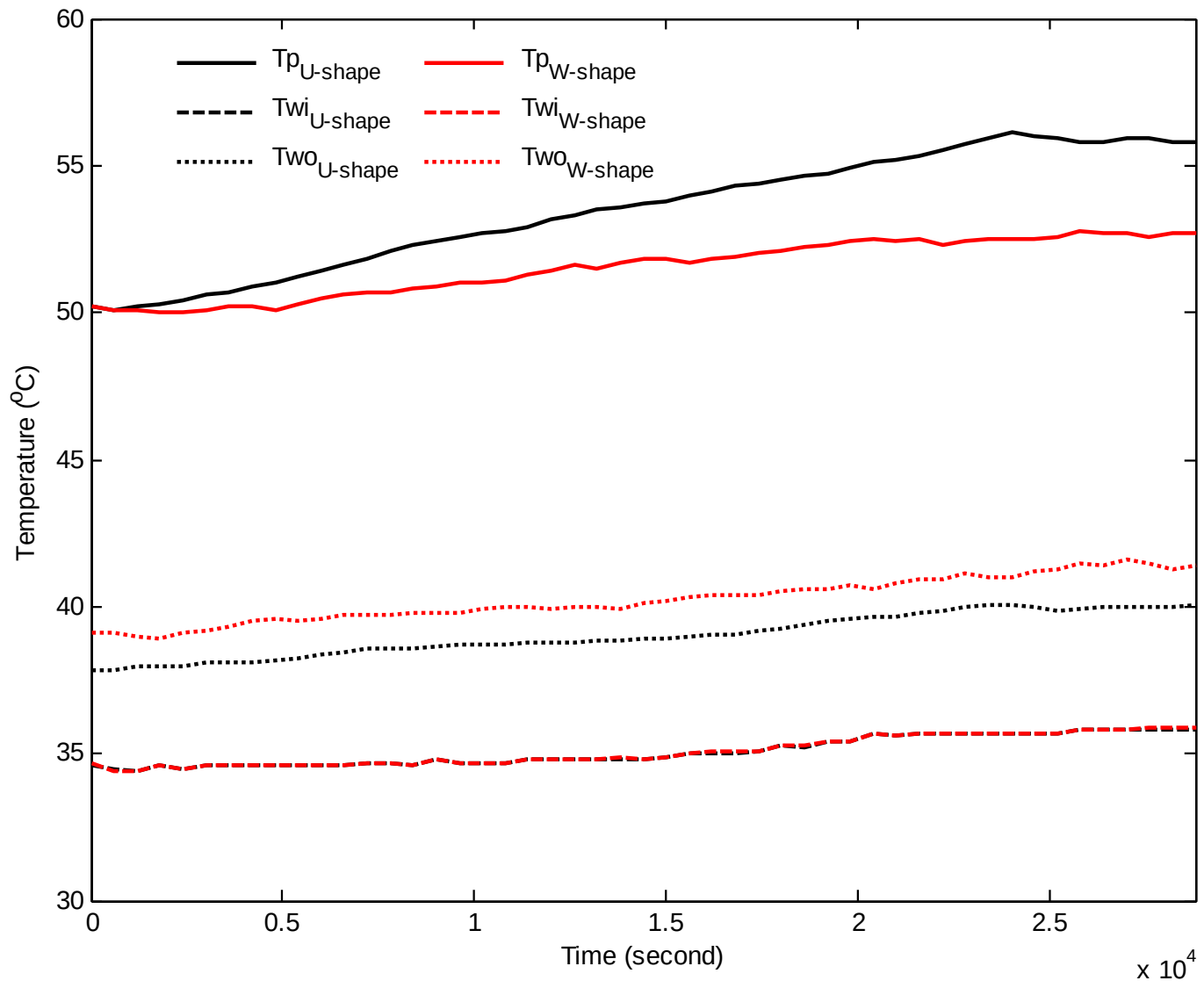

261

Fig. 8 Comparison of temperature profile of plating solution, water inlet and outlet at the electroplating bath with the cooling water flow velocity at $2.0 \mathrm{~m} \cdot \mathrm{s}^{-1}$.

\section{Conclusions}

To control the temperature of the hard chromium electroplating bath, an effective heat exchanger is needed to remove heat occurred during the electroplating process. In this work, heat removals of two tube heat exchangers have been compared. In addition, mathematical models of the hard chromium electroplating process have been formulated to predict the dynamics temperature of the electroplating bath and evaluate the heat exchanger performance. Unknown parameters in the developed models are determined based on the actual plant data. The simulation results show that the developed models can give a good accurate prediction of the 
272 plating solution temperature with the coefficient of determination $\left(R^{2}\right)$ of more than $90 \%$. The 273 heat removal performances of 1.27 and $2.54 \mathrm{~cm}$ diameter of the $\mathrm{W}$ serpentine shape tube heat 274 exchangers with the flow velocity in a cross-section at $1.6,2.0$ and $2.4 \mathrm{~m} \cdot \mathrm{s}^{-1}$ are compared. The 275 simulation results indicate that the $\mathrm{W}$ serpentine shape with $2.54 \mathrm{~cm}$ diameter is applicable to 276 maintain the plating solution temperature at the desired range at any flow velocity. Furthermore, 277 four W serpentine shape tube heat exchangers with identical heat transfer area to the U shape 278 tube heat exchanger (2.54 cm diameter and $30 \mathrm{~m}$ in total length) are implemented in the real 279 electroplating bath. The plating solution temperature after the implementation can be kept at the 280 range. Moreover, the novel design provides higher heat removal than the conventional U shape 281 tube heat exchanger around $23 \%$. 


\section{Acknowledgements}

The authors would like to thank Thailand Research Fund (TRF) under The Royal Golden

Heat transfer area of a tube heat exchanger, $\mathrm{m}^{2}$

Cross section area of a tube heat exchanger, $\mathrm{m}^{2}$

Contacted area of the surface of plating solution with surroundings, $\mathrm{m}^{2}$

Surface area between water droplet and air, $\mathrm{m}^{2}$

Specific heat capacity of plating solution, $\mathrm{kJ} \cdot \mathrm{kg}^{-1 .{ }^{\circ}} \mathrm{C}^{-1}$

Specific heat capacity of water, $\mathrm{kJ} \cdot \mathrm{kg}^{-1 .}{ }^{\circ} \mathrm{C}^{-1}$

Water blowdown rate of a cooling tower, $\mathrm{m}^{3} \cdot \mathrm{s}^{-1}$

Inlet volumetric water flow rate of a cooling tower, $\mathrm{m}^{3} \cdot \mathrm{s}^{-1}$

Outlet volumetric water flow rate of a cooling tower, $\mathrm{m}^{3} \cdot \mathrm{s}^{-1}$

Water drift loss of a cooling water, $\mathrm{m}^{3} \cdot \mathrm{s}^{-1}$

Water evaporation rate in a cooling tower, $\mathrm{m}^{3} \cdot \mathrm{s}^{-1}$

Water makeup to a cooling tower, $\mathrm{m}^{3} \cdot \mathrm{s}^{-1}$

Volumetric flow rate of cooling water from other electroplating baths to a cooling tower, $\mathrm{m}^{3} \cdot \mathrm{s}^{-1}$

$F_{\text {over }} \quad$ Volumetric flow rate of cooling water from a water reservoir tank 2 overflows to a water reservoir tank $1, \mathrm{~m}^{3} \cdot \mathrm{s}^{-1}$ 


\begin{tabular}{|c|c|c|}
\hline 304 & $F_{\mathrm{w}}$ & Volumetric flow rate of cooling water, $\mathrm{m}^{3} \cdot \mathrm{s}^{-1}$ \\
\hline 305 & $F_{\mathrm{t}}$ & Heat exchanger correction factor \\
\hline 306 & $h_{\mathrm{A}}$ & Heat transfer coefficient of convection between water and air, $\mathrm{W} \cdot \mathrm{m}^{-2 .{ }^{\circ}} \mathrm{C}^{-1}$ \\
\hline 307 & $I$ & Electric current, A \\
\hline 308 & $L_{\text {tube }}$ & Length of a tube heat exchanger, $\mathrm{m}$ \\
\hline 309 & $Q_{\text {loss }}$ & Heat loss from an upper surface of the plating solution to surroundings, W \\
\hline 310 & $T_{\text {air }}$ & Air temperature, ${ }^{\circ} \mathrm{C}$ \\
\hline 311 & $T_{\text {avg }}$ & Average different water temperature at a cooling tower, ${ }^{\circ} \mathrm{C}$ \\
\hline 312 & $T_{\mathrm{ci}}$ & Water temperature at a water reservoir tank $1,{ }^{\circ} \mathrm{C}$ \\
\hline 313 & $T_{\text {co }}$ & Outlet water temperature in a cooling tower, ${ }^{\circ} \mathrm{C}$ \\
\hline 314 & $t_{\mathrm{f}}$ & Total operation time, $\mathrm{s}$ \\
\hline 315 & $T_{\text {makeup }}$ & Water makeup temperature, ${ }^{\circ} \mathrm{C}$ \\
\hline 316 & $T_{\text {other }}$ & Outlet water temperature from other electroplating baths, ${ }^{\circ} \mathrm{C}$ \\
\hline 317 & $T_{\mathrm{p}}$ & Plating solution temperature, ${ }^{\circ} \mathrm{C}$ \\
\hline 318 & $T_{\text {p,actual }}$ & Plating solution temperature which collected from a real plant, ${ }^{\circ} \mathrm{C}$ \\
\hline 319 & $T_{\text {p,simulation }}$ & Plating solution temperature from simulation, ${ }^{\circ} \mathrm{C}$ \\
\hline 320 & $T_{\text {simulation }}$ & Temperature results from the simulation, ${ }^{\circ} \mathrm{C}$ \\
\hline 321 & $T_{\text {wi }}$ & Inlet cooling water temperature, ${ }^{\circ} \mathrm{C}$ \\
\hline 322 & $T_{\text {wi,actual }}$ & Inlet cooling water temperature which collected from a real plant, ${ }^{\circ} \mathrm{C}$ \\
\hline 323 & $T_{\text {wo }}$ & Outlet cooling water temperature, ${ }^{\circ} \mathrm{C}$ \\
\hline 324 & $T_{\text {wo,actual }}$ & Outlet cooling water temperature which collected from a real plant, ${ }^{\circ} \mathrm{C}$ \\
\hline 325 & $T_{2}$ & Water temperature at a water reservoir tank $2,{ }^{\circ} \mathrm{C}$ \\
\hline
\end{tabular}


$\Delta T_{\operatorname{lm}}$

$v$

V

$V_{\text {c }}$

$V_{\mathrm{p}}$

$V_{\mathrm{T} 1}$

$V_{\mathrm{T} 2}$

$V_{\text {tube }}$

$U_{\mathrm{o}}$

$\lambda_{\text {evap }}$

$\rho_{\mathrm{p}}$

$\rho_{\mathrm{w}}$

$\mu_{\mathrm{w}}$

Logarithmic mean temperature at a tube heat exchanger, ${ }^{\circ} \mathrm{C}$

Flow velocity in a cross-section of a tube heat exchanger, $\mathrm{m} \cdot \mathrm{s}^{-1}$

Electrical voltage, $\mathrm{V}$

Volume of a cooling tower, $\mathrm{m}^{3}$

Volume of an electroplating bath, $\mathrm{m}^{3}$

Volume of a water reservoir tank $1, \mathrm{~m}^{3}$

Volume of a water reservoir tank $2, \mathrm{~m}^{3}$

Volume of a tube heat exchanger, $\mathrm{m}^{3}$

Overall heat transfer coefficient, $\mathrm{kW} \cdot \mathrm{m}^{-2 .{ }^{\circ}} \mathrm{C}^{-1}$

Latent heat of vaporization of water, $\mathrm{kJ} \cdot \mathrm{kg}^{-1}$

Density of plating solution, $\mathrm{kg} \cdot \mathrm{m}^{-3}$

Density of water, $\mathrm{kg} \cdot \mathrm{m}^{-3}$

Dynamic viscosity of water, $\mathrm{kg} \cdot \mathrm{m}^{-1} \cdot \mathrm{s}^{-1}$ 


\section{References}

[1] E. Svenson, DuraChrome hard chromium plating, Plating resources, Inc., Florida, 2006, pp. 1-40.

[2] G.A. Lausmann, Electrolytically deposited hard chrome, Surf. and Coat. Technol 86-87 (1996), pp. 814-820.

[3] N.V. Mandich, D.L. Snyder, Modern electroplating, fifth ed., John Wiley \& Sons, New Jersy, 2010, pp. 205-248.

[4] A.K. Graham, Electroplating Engineering Handbook, Reinhold, U.S.A., 1955.

[5] L. Zitko, G. Cushnie, P. Chalmer, R. Taylor, Hard chrome plating training course, The National Center for Manufacturing Sciences, Michigan, 2010.

[6] F.A. Lowenheim, Modern Electroplating, $3^{\text {rd }}$ Ed., J Wiley \& Son, U.S.A., 1974.

[7] S. Tanthadiloke, P. Kittisupakorn, I. M. Mujtaba, Improvement of production performance of a hard chromium electroplating via operational optimization. Proc. $5^{\text {th }}$ Reg. Conf. Chem. Eng., Thailand (2013) 221-224.

[8] S. Tanthadiloke, P. Kittisupakorn, I. M. Mujtaba, Modeling and design a controller for improving the plating performance of a hard chromium electroplating process, Comput. Aided Chem. Eng. 33 (2014) 805-810.

[9] D.G. Prabhanjan, G.S.V. Paghavan, Comparison of heat transfer rates between a straight tube heat exchanger and a helically coiled heat exchanger, Int. J. Heat Mass Transf. 29 (2005) 185-191. 
359 [10] Y.A. Çengel, Heat Transfer: A Practical Approach, 2nd Ed., McGraw-Hill, U.S.A., 2003.

360 [11] S. Niamsuwan, P. Kittisupakorn, I. M. Mujtaba, A newly designed economizer to

361

362

363

364

365

366

367

368

369

370

371

372

373

374

375

376

377

378 improve waste heat recovery: A case study in a pasteurized milk plant, J. Appl. Them. Eng. 60 (2013) 188-199.

[12] A. Zachar, Analysis of coiled-tube heat exchangers to improve heat transfer rate with spirally corrugated wall, Int. J. Heat Mass Transf. 53 (2010) 3928-3939.

[13] P. Naphon, S. Wongwises, A review of flow and heat transfer characteristics in curved tubes, Renew. Sustain. Energy Rev. 10 (2006) 463-490.

[14] W. Lin, N. Qiao. In-plan vibration analyses of curved pipes conveying fluid using the generalized differential quadrature rule, Comput. Struct. 86 (2008) 133-139.

[15] S. Gunes, V. Ozceyhan, B. Orhan, Heat transfer enhancement in tube with equilateral triangle cross sectioned coiled wire inserts, Exp. Therm. Fluid Sci. 34 (2010) 684-691.

[16] S. Gunes, V. Ozceyhan, The experimental investigation of heat transfer and pressure drop in a tube with coiled wire inserts placed separately from the tube wall, Appl. Therm. Eng. 30 (2010) 1719-1725.

[17] L. Cheng, T. Luan, W.D.M. Xu, Heat transfer enhancement by flow-induced vibration in heat exchangers, Int. J. Heat Mass Transf. 52 (2009) 1053-1057.

[18] A. Thaikua, P. Kittisupakorn, S. Tanthadiloke, Temperature control by heat exchanger incorporating with vibration type coiled-tube, Proc. Int. Multiconf. Eng. Comput. Sci. 2012 Vol II, Hong Kong (2012) 1357-1361. 
[19] V. Kumar, P. Gupta, K. D. P. Nigam, Fluid flow and heat transfer in curved tubes with temperature-dependent properties, Ind. Rng. Chem. Res. 46(2007) 3226-3236.

[20] M. Yasuo, N. Wataru, Study on forced convective heat transfer in curved pipes, Int. J. Heat Mass Transf. 8 (1965) 67-82.

[21] R. Yang, S. F. Chang, W. Wu, Flow and heat transfer in a curved pipe with periodically varying curvature, Int. Commun. Heat Mass Transf. 27(2000) 133-143.

[22] C. Camci, D. H. Rizzo, Secondary flow and forced convection heat transfer near endwall boundary layer fences in a $90^{\circ}$ turning duct, Int. J. Heat Mass Transf. 45 (2002) 831-843.

[23] B.W. Bequette, Process Dynamics Modeling, Analysis, and Simulation, $1^{\text {st }}$ Ed., Prentice Hall, U.S.A., 1998.

[24] F.P. Incropera, D. P. DeWitt, Fundamentals of Heat and Mass Transfer, $6^{\text {th }}$ Ed., J Wiley \& Son, U.S.A., 2007.

[25] R.B. Bird, W.E. Stewart, E.N. Lightfoot, Transport Phenomena, $2^{\text {nd }}$ Ed., J Wiley \& Son, U.S.A., 1998.

[26] P. Naphon, Study on heat transfer characteristics of an evaporative cooling tower, Int. Commun. Heat Mass Transf. 32 (2005) 1066-1074.

[27] R.H. Perry, Perry's Chemical Engineering Handbook, 6 ${ }^{\text {th }}$ Ed., McGraw-Hill, U.S.A., 1984.

[28] C. Veiga, J. P. Davim, A. J. R. Loureiro, Properties and application of titanium alloys: A brief review, Rev. Adv. Mater. Sci. 32 (2012) 133-148. 


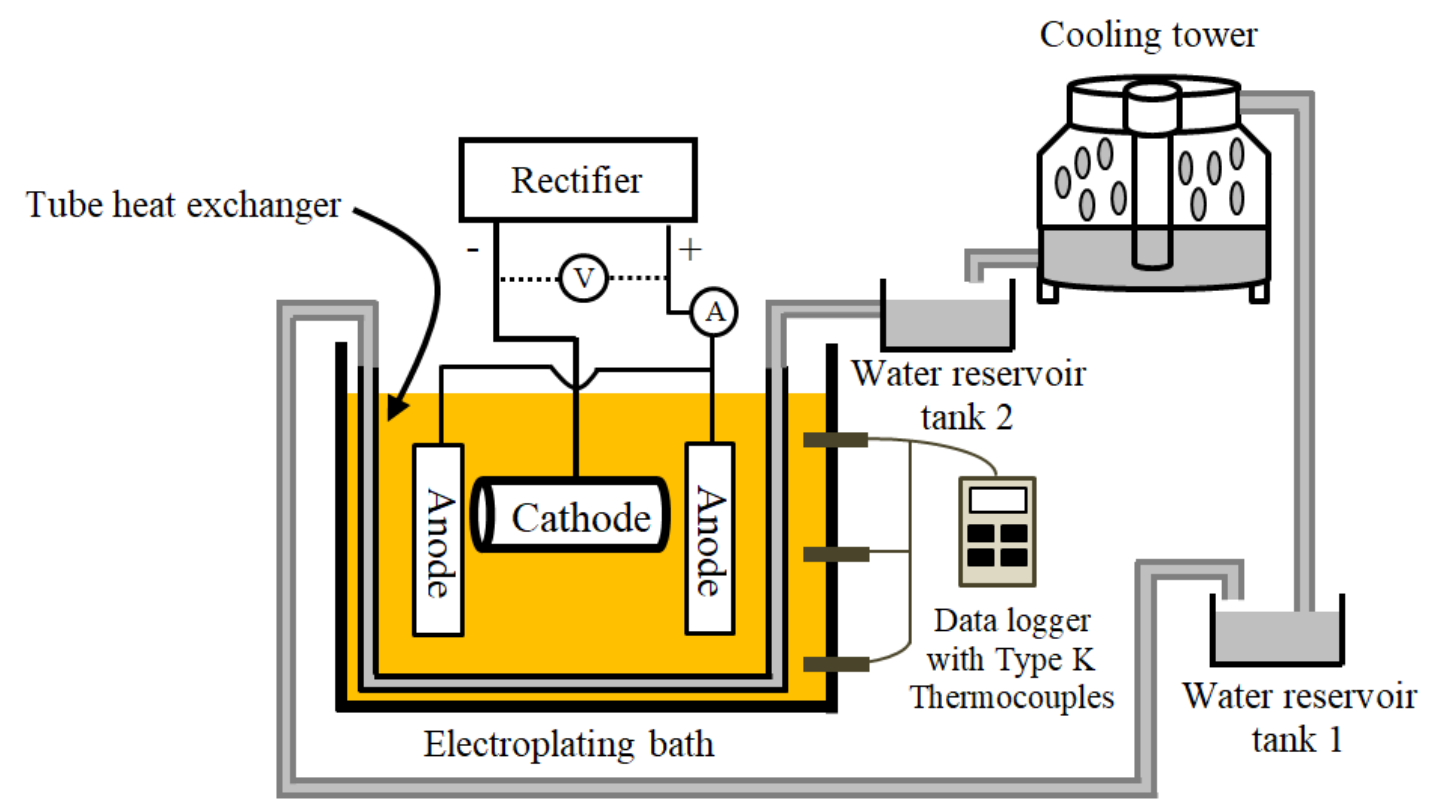

Fig. 1 Hard chromium electroplating process with the cooling system.

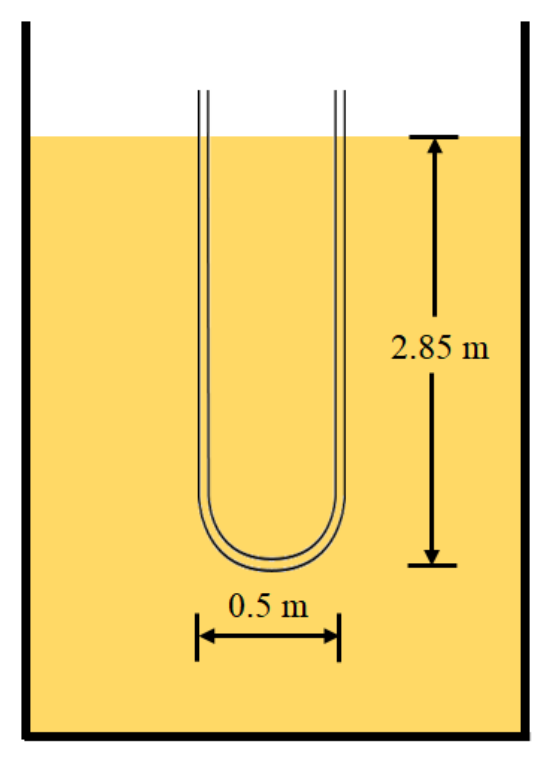

(a)

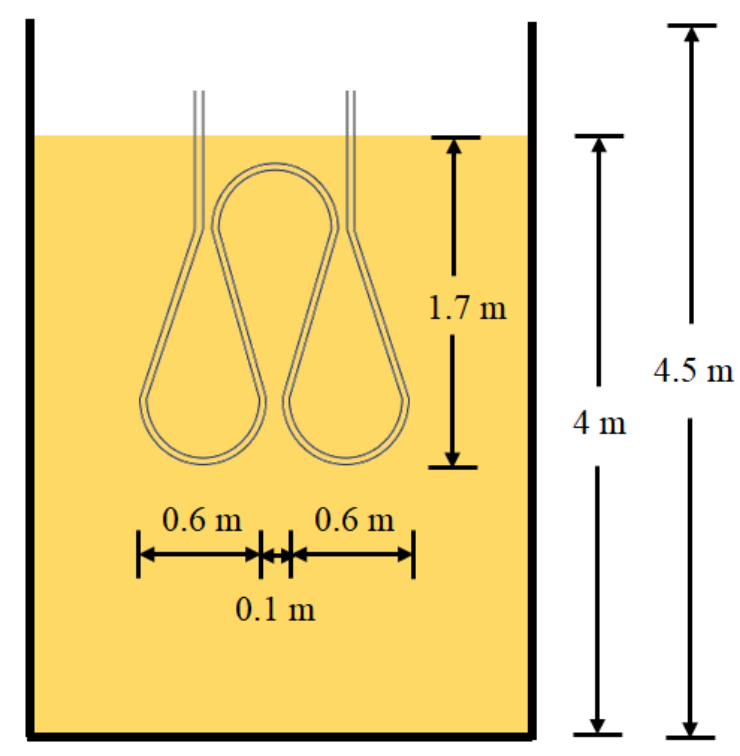

(b)

Fig. 2 Illustration of the heat exchangers inside the hard chromium electroplating bath:

(a) U shape heat exchanger and (b) W serpentine shape heat exchanger. 


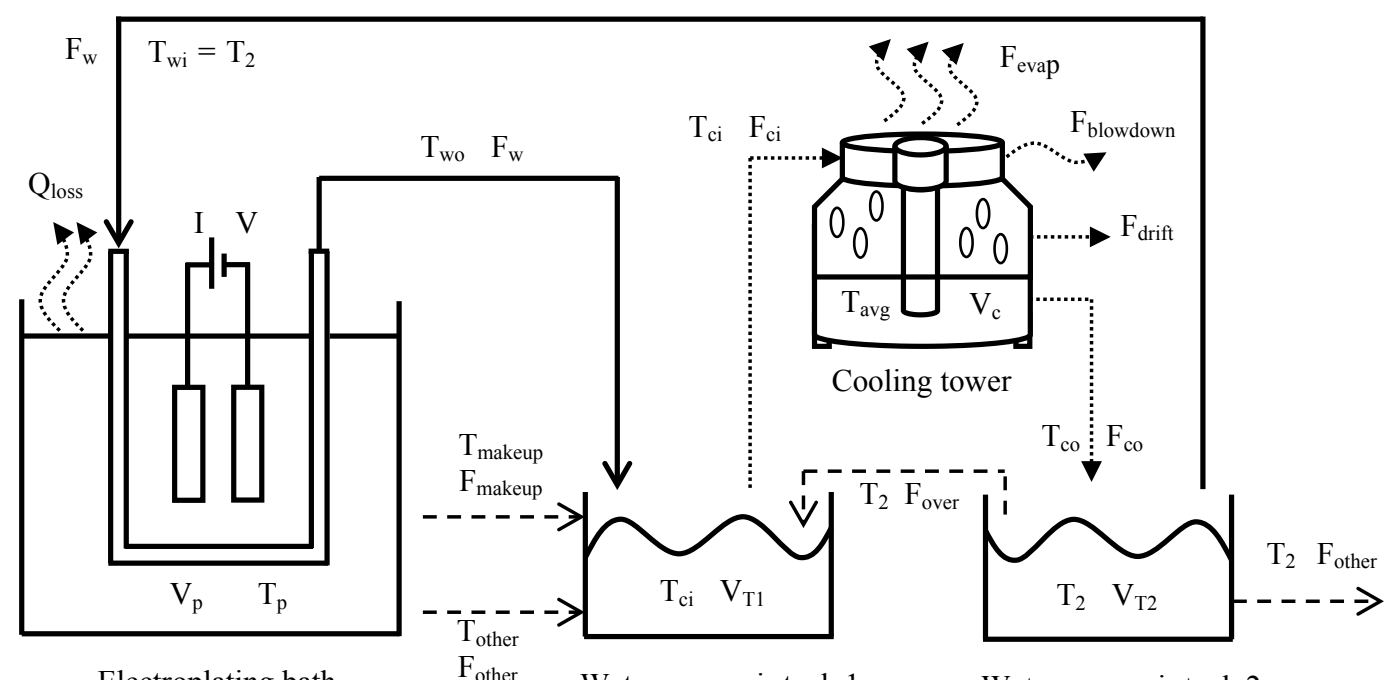

Electroplating bath

Water reservoir tank 1

Water reservoir tank 2

Fig. 3 Schematic diagram of the hard chromium electroplating process with mass and energy balance.

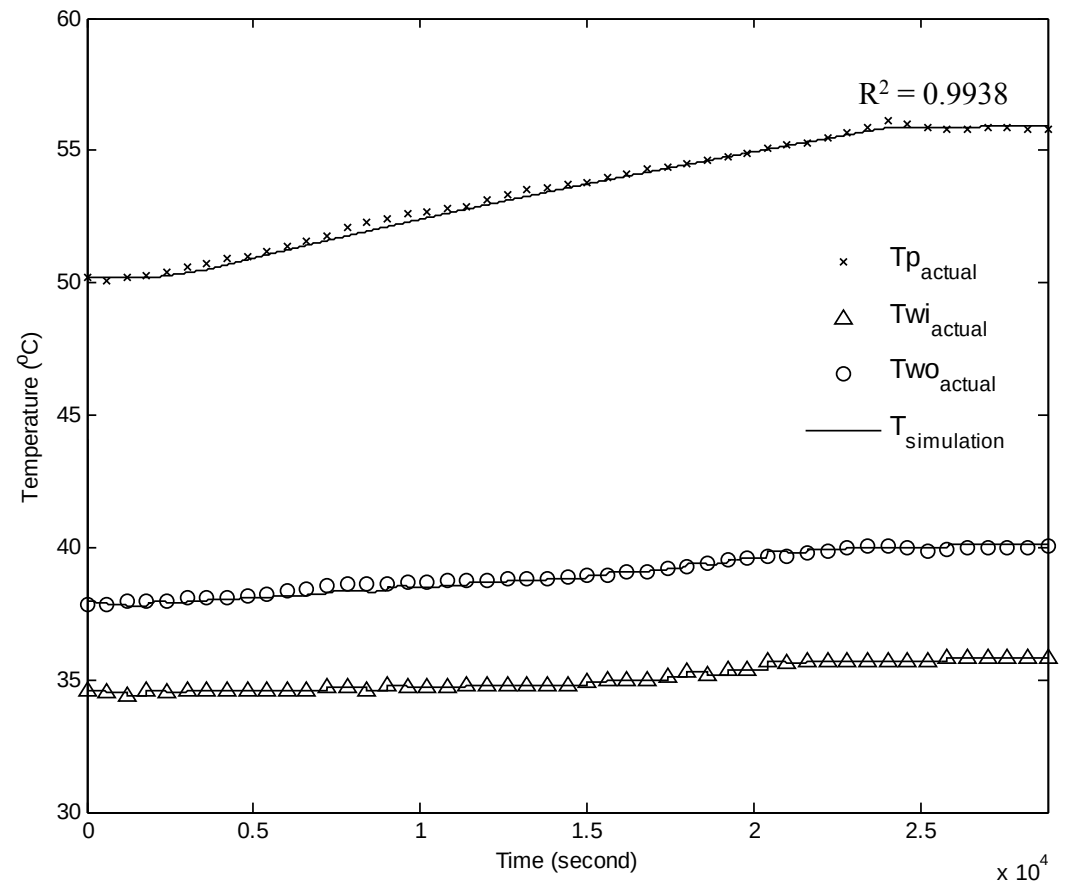

Fig. 4 Comparison results between simulation and actual data of plating solution temperature and water temperature at inlet and outlet of the electroplating bath. 


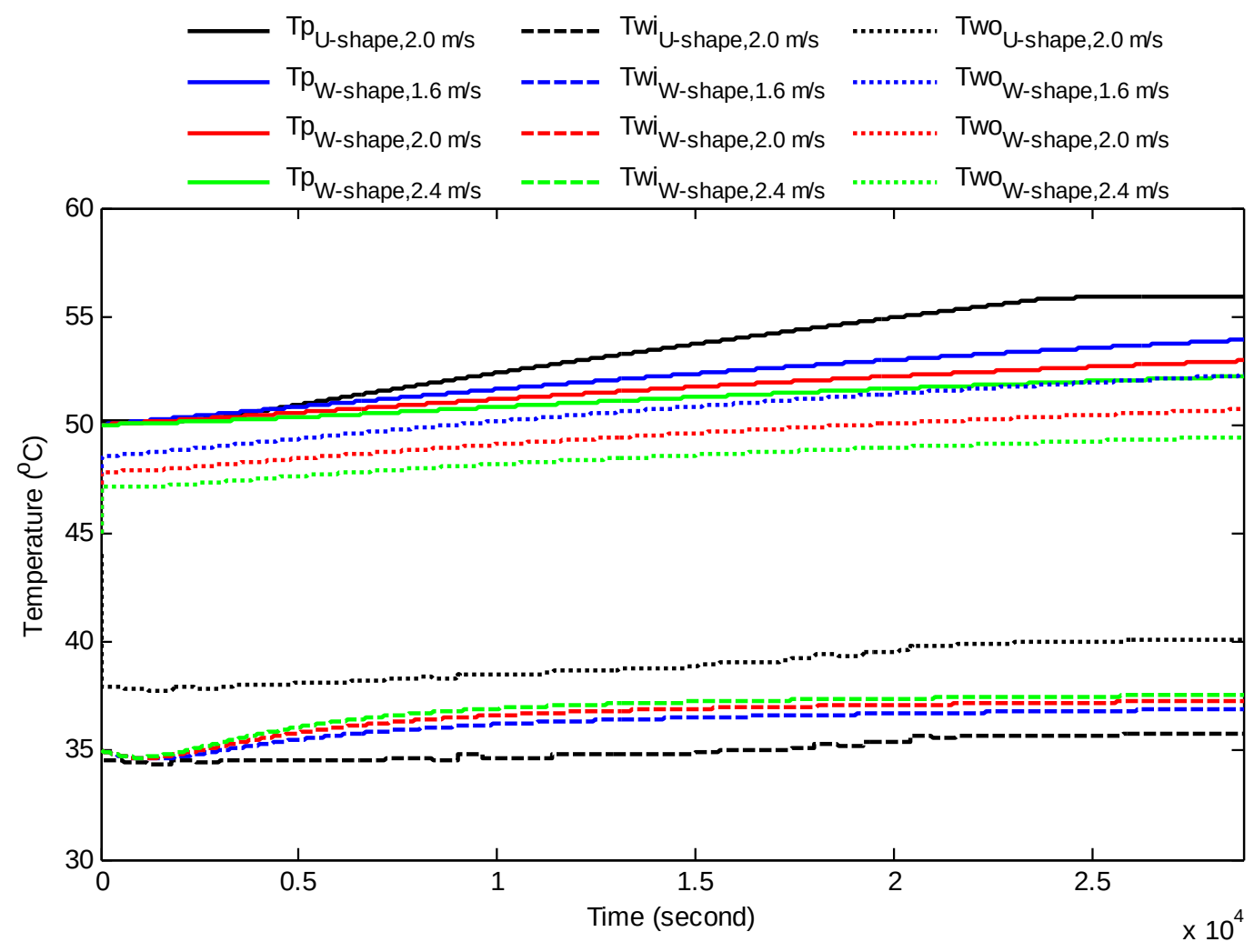

Fig. 5 The temperature profile of plating solution, water inlet and outlet at the electroplating bath for $1.27 \mathrm{~cm}$ diameter of $\mathrm{W}$ serpentine shape tube heat exchanger at various water velocities. 


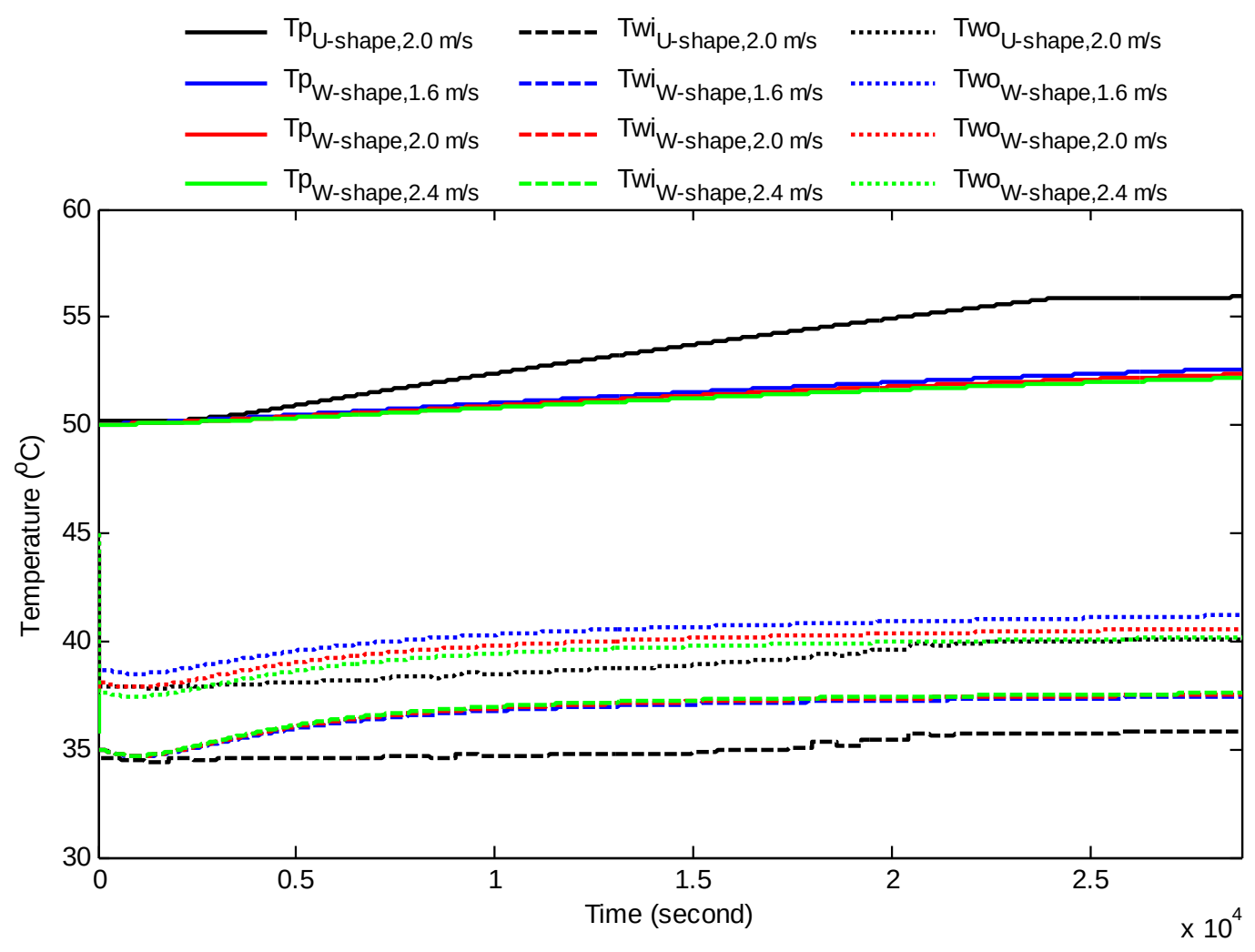

Fig. 6. The temperature profile of plating solution, water inlet and outlet at the electroplating bath for $2.54 \mathrm{~cm}$ diameter of $\mathrm{W}$ serpentine shape tube heat exchanger at various water velocities. 


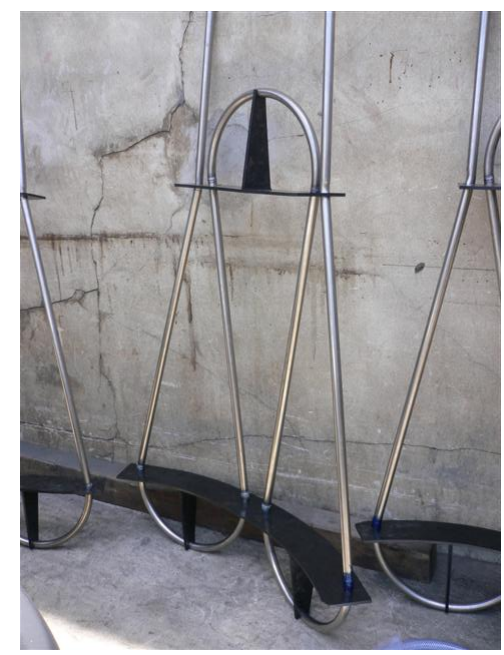

(a) The W serpentine shape tube heat exchanger.

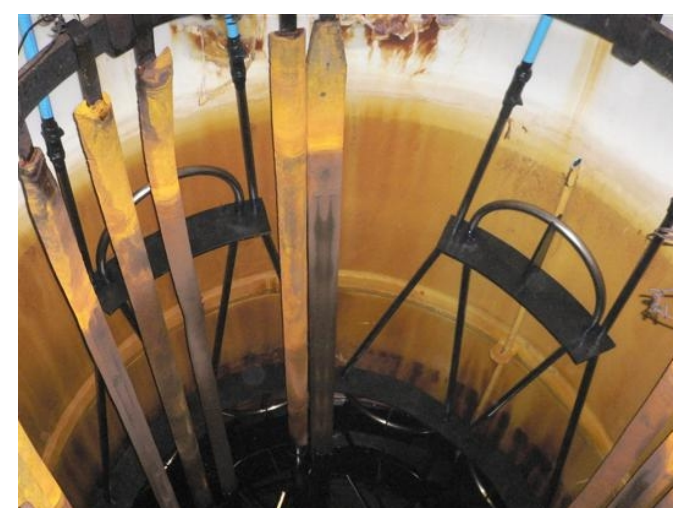

(b) The installation of the $\mathrm{W}$ serpentine shape tube heat exchanger in the electroplating bath.

Fig. 7 The implementation of $\mathrm{W}$ serpentine shape tube heat exchanger. 


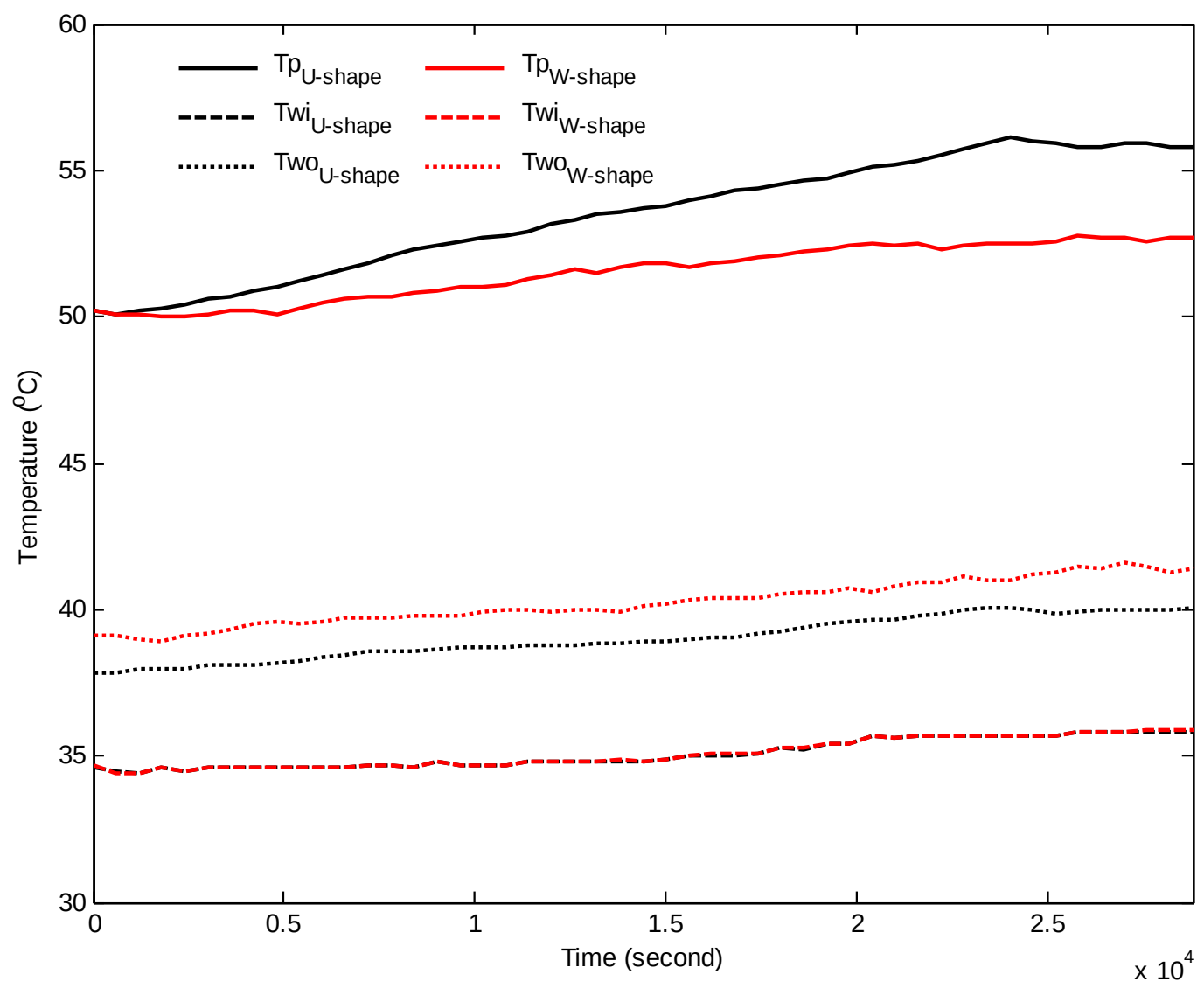

Fig. 8 Comparison of temperature profile of plating solution, water inlet and outlet at the electroplating bath with the cooling water flow velocity at $2.0 \mathrm{~m} / \mathrm{s}$. 


\section{Table 1}

Physical properties [27, 28].

\begin{tabular}{lcc}
\hline \multicolumn{1}{c}{ Physical property } & Unit & Value \\
\hline Density of water & $\mathrm{kg} / \mathrm{m}^{3}$ & 992.25 \\
Density of plating solution & $\mathrm{kg} / \mathrm{m}^{3}$ & $1,174.4$ \\
Heat capacity of water & $\mathrm{kJ} / \mathrm{kg} \cdot{ }^{\circ} \mathrm{C}$ & 4.181 \\
Heat capacity of plating solution & $\mathrm{kJ} / \mathrm{kg} \cdot{ }^{\circ} \mathrm{C}$ & 4.917 \\
Latent heat of vaporization of water & $\mathrm{kJ} / \mathrm{kg}$ & 2,260 \\
Thermal conductivity of titanium & $\mathrm{kW} / \mathrm{m} \cdot{ }^{\circ} \mathrm{C}$ & 0.0206 \\
\hline
\end{tabular}

Table 2

Simulation system geometric characteristics.

\begin{tabular}{lcc}
\hline \multicolumn{1}{c}{ System characteristic } & Unit & Value \\
\hline Inner diameter of a $1.27 \mathrm{~cm}$ diameter tube heat exchanger & $\mathrm{m}$ & 0.0111 \\
Outer diameter of a $1.27 \mathrm{~cm}$ diameter tube heat exchanger & $\mathrm{m}$ & 0.0127 \\
Inner diameter of a $2.54 \mathrm{~cm}$ diameter tube heat exchanger & $\mathrm{m}$ & 0.0238 \\
Outer diameter of a $2.54 \mathrm{~cm}$ diameter tube heat exchanger & $\mathrm{m}$ & 0.0254 \\
Volume of an electroplating bath & $\mathrm{m}^{3}$ & 9.3062 \\
Volume of a water tank 1 & $\mathrm{m}^{3}$ & 2.1155 \\
Volume of a water tank 2 & $\mathrm{m}^{3}$ & 2.5663 \\
Volume of a cooling tower & $\mathrm{m}^{3}$ & 0.3771 \\
\hline
\end{tabular}




\section{Table 3}

Operating conditions for simulation.

\begin{tabular}{lcc}
\hline \multicolumn{1}{c}{ Operating condition } & Unit & Value \\
\hline $\begin{array}{l}\text { Outlet water temperature to other } \\
\text { electroplating baths }\end{array}$ & ${ }^{\circ} \mathrm{C}$ & 44.1 \\
Water make up temperature & ${ }^{\circ} \mathrm{C}$ & 34.9 \\
Air temperature & ${ }^{\circ} \mathrm{C}$ & 30 \\
$\begin{array}{l}\text { Volumetric flow rate of cooling water in other } \\
\text { electroplating baths flow to a cooling tower }\end{array}$ & $\mathrm{m}^{3} / \mathrm{s}$ & $4.3364 \times 10^{-4}$ \\
Water make up to a cooling tower & $\mathrm{m}^{3} / \mathrm{s}$ & $7.7597 \times 10^{-6}$ \\
Water evaporation rate in a cooling tower & $\mathrm{m}^{3} / \mathrm{s}$ & $4.3238 \times 10^{-6}$ \\
Water blow down rate of a cooling tower & $\mathrm{m}^{3} / \mathrm{s}$ & $1.0809 \times 10^{-6}$ \\
Water drift loss of a cooling water & $\mathrm{m}^{3} / \mathrm{s}$ & $2.3550 \times 10^{-6}$ \\
\hline
\end{tabular}

